研

究

\title{
$\left(\mathrm{Y}_{1-\mathrm{x}} S \mathrm{~m}_{\mathrm{x}}\right)_{2} \mathrm{Fe}_{14} \mathrm{~B}$ 化合物の自然共鳴と電磁波吸収
}

\author{
前田 徹, 手束 展規, 籠谷登志夫, 杉本 諭, 猪俣浩一郎 \\ 東北大学大学院工学研究科材料物性学専攻, $\overline{9} 980-8579$ 仙台市青葉区荒巻字青葉 02.
}

\section{Natural Resonance Phenomena and GHz-range Microwave Absorption of the $\left(\mathrm{Y}_{1-\mathrm{x}} \mathrm{Sm}_{\mathrm{x}}\right)_{2} \mathrm{Fe}_{14} \mathrm{~B}$ Compound}

\author{
Toru Maeda, Nobuki Tezuka, Toshio Kagotani, Satoshi Sugimoto and Koichiro Inomata \\ Dept. Materials Science, Graduate School of Engineering, Tohoku University, Aramaki-Aoba02, Aoba-ku, Sendai 980-8579.
}

Received September 2, 2002

\section{SYNOPSIS}

The RE-Fe-B (RE=Rare earth) compounds have a possibility to be used as electromagnetic (EM) wave absorption materials in the $\mathrm{GHz}$ range, because of their high saturation magnetization and large anisotropy field. This paper describes the natural resonance phenomena and the $\mathrm{EM}$ wave absorption properties of $\mathrm{Sm}$-substituted $\mathrm{Y}_{2} \mathrm{Fe}_{14} \mathrm{~B}$ resin composites, which were measured in the $\mathrm{GHz}$ frequency range. The $\left(\mathrm{Y}_{1-\mathrm{x}} \mathrm{Sm}_{\mathrm{x}}\right)_{2} \mathrm{Fe}_{14} \mathrm{~B}$ powders showed an uniaxial anisotropy in the samples of $x=0$ to 0.12 , and their anisotropy fields decreased with increasing $x$ value. However, the easy axis of magnetization changed to basal plane in the samples of $x>0.15$. The natural resonance frequency $\left(f_{r}\right)$ of the sample with $x=0$, was calculated as $51.0 \mathrm{GHz}$ from its anisotropy field. The calculated $\mathrm{f}_{\mathrm{r}}$ value showed a tendency to decrease with increasing $x$ value and exhibited a minimum value of $20.8 \mathrm{GHz}$ in the sample of $x=0.15$. The magnetic resonance phenomenon were observed in the epoxy resin composites of these powders, and the resonance frequencies showed a good agreement with their calculated $f_{\mathrm{r}}$ values. The $\mathrm{x}=0.10$ sample absorbed the EM wave over $99 \%$ at $22 \mathrm{GHz}$ with the thickness of $0.69 \mathrm{~mm}$, which is $30 \%$ thinner than that of the M-type ferrite/resin absorber. It can be considered that the sample can function as an electromagnetic wave absorber at frequencies around $22 \mathrm{GHz}$, where one kind of wireless LANs is now planned.

KEY WORDS

electromagnetic wave absorber, $\mathrm{Y}_{2} \mathrm{Fe}_{14} \mathrm{~B}$ compound, samarium, natural resonance, reflection loss

\section{1 緒 言}

近年，携帯電話 $(1.5,2.0 \mathrm{GHz})$ や無線 LAN $(2.45,5.0 \mathrm{GHz})$ な ビの準マイクロ波帯 $(300 \mathrm{MHz}-3 \mathrm{GHz})$ 電磁波を利用した情報 通信機器が急速に普及している。しかしながら，これらの電 磁波が医療機器，コンピュータなどの電子機器の誤作動を引 き起こす電磁干渉(EMI: Electromagnetic Interference)が大きな 問題となっている. この電磁干㗪対策の一つとして電磁波吸 収体があり"，準マイクロ波帯では，スピネル型フエライトお よび鉄系軟磁性材料の樹脂複合体の磁気共鳴によって生じる 磁性損失を利用した電磁波吸収体が報告されている．既に無 線LANの使用周波数として 19.0,22.0,26.0, 60.0GHzが割り当 てられていることからも，今後はより大容量・多チャンネル のデータ伝送が可能となる 10〜 $100 \mathrm{GHz}$ といった高い周波数 帯域の電磁波の利用が増加すると予想され，これに対応した
電磁波吸収体が必要になると考えられる。これまでにこの帯 域で機能する電磁波吸収体として自然共鳴を利用した磁性損 失型の $\mathrm{M}$ 型フェライト ${ }^{2-4)}$ や誘電損失型のカーボンゴム複合

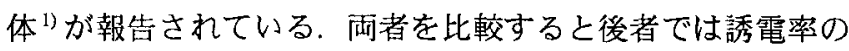
みでの制御となるため対応周波数帯域や吸収体の厚さがカ一 ボン充填率で決まるのに対し，前者では誘電率だけでなく材 料の結晶磁気異方性の制御により，共鳴周波数を調節できる. 結果的に吸収特性制御の自由度が多くなり，吸収帯域の広帯 域化が可能となるなどメリットが多い.

$\mathrm{M}$ 型フェライトの一種である $\mathrm{BaFe}_{12} \mathrm{O}_{19}$ の自然共鳴周波数 $\mathrm{f}_{\mathrm{r}}$ は，その異方性磁界 $\mathrm{H}_{\mathrm{A}}=1.35 \mathrm{MA} / \mathrm{m}$ から計算すると $48 \mathrm{GHz}$ と なる．また Feの一部を(TiMn)や $\mathrm{Al}$ などで置換することで $\mathrm{f}_{\mathrm{r}}$ を $5 \sim 150 \mathrm{GHz}$ の範囲で制御できる.この材料は焼結体とし て薄型吸収体となるが，吸収帯域幅が狭い，加工し難いとい 
う問題点から，樹脂などと複合化することが多い。ここで内 藤のによると，インピーダンス整合型電磁波吸収体における 近似的な吸収体原さは $\mu_{\mathrm{r}}$ の值に反比例するとされており，ま た回転磁化の初透磁率は(1)式のように表される?

$$
\mu_{i}=1+\left(2 J_{S}\right) /\left(3 \mu_{0} H_{A}\right)
$$

ここでI $\mathrm{I}_{\mathrm{S}}$ は有効飽和磁化， $\mathrm{H}_{\mathrm{A}}$ は異方性磁界である.すなわち 初透磁率は磁化の值に比例しており，磁化が低下すると自然 共鳴による磁性損失が低下してしまう。したがって複合化に より吸収体の有効飽和磁化が低下し，吸収体厚さが大きく なってしまうことが問題となる.

そこで $\mathrm{M}$ 型フェライトと同様 $\mathrm{GHz}$ 帯域で自然共鳴を示し， 且つ飽和磁化の大きな金属系の材料が複合体用フィラー材料 として有効であるといえる． $\mathrm{Y}_{2} \mathrm{Fe}_{14} \mathrm{~B}$ 化合物》浪飽和磁化が $\mathrm{I}_{\mathrm{s}}=1.42 \mathrm{~T}$ とフェライト系の $4 \sim 5$ 倍の值である. また異方性 磁界は $\mathrm{H}_{\mathrm{A}}=1.60 \mathrm{MA} / \mathrm{m}$ と $\mathrm{M}$ 型フエライトと同等の一軸磁気異 方性を示し，これより計算される自然共鳴周波数 $\mathrm{f}_{\mathrm{r}}$ も $56 \mathrm{GHz}$ となる.ここで同じ結晶構造を有する $\mathrm{Nd}_{2} \mathrm{Fe}_{14} \mathrm{~B}$ 化合物では, $\mathrm{Nd}$ の Sm 置換により一軸磁気異方性から面内異方性に移行す $ろ^{8)}$ と報告されている， $\mathrm{Y}_{2} \mathrm{Fe}_{14} \mathrm{~B}$ 系においても同様の $\mathrm{Sm}$ 置換 の効果が期待され，組成制御により任意周波数での自然共鳴 現象およびそれに伴う電磁波吸収が得られると考えられる。 また金属材料であることから自然共鳴を起こさせるためには フィラー粉末を表皮深さ $(50 \mathrm{GHz}$ で約 $2 \mu \mathrm{m})$ 程度にすることが 必要となるが，この材料は脆性が高いことからボールミルな ぞを用いた機械粉厒によりこの粒子径を実現することが可能 であるといえる. 以上より高飽和磁化を有する $\mathrm{Y}_{2} \mathrm{Fe}_{14} \mathrm{~B}$ 化合物 を用いGHz带域て機能する電磁波吸収体の薄型化が達成可能 であると考えられる. 本研究では $\left(\mathrm{Y}_{1-\mathrm{S}} \mathrm{Sm}_{\mathrm{x}}\right)_{2} \mathrm{Fe}_{14} \mathrm{~B}$ 化合物粉末 の樹脂複合体を作製し，高周波帯域での自然共鳴現象および 電磁波吸収特性を調べた。

\section{2 試料作製および実験方法}

イットリウム (純度 99.9 mass\%), サマリウム (99.9 mass\%), 電解鉄(99.9 mass\%)およびクリスタルボロン $(99.5$ mass\%)を組
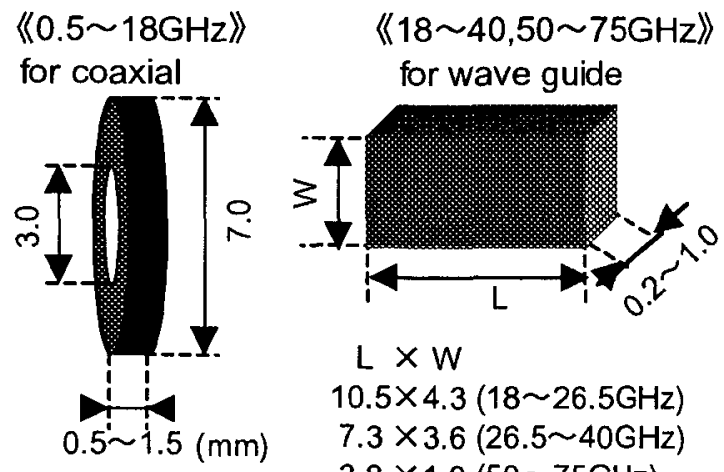

$\mathrm{L} \times \mathrm{W}$ $10.5 \times 4.3(18 \sim 26.5 \mathrm{GHz})$ $7.3 \times 3.6(26.5 \sim 40 \mathrm{GHz})$ $3.8 \times 1.9(50 \sim 75 \mathrm{GHz})$

Fig.1 Sample shapes for the measurement with a network analyzer.
成 $\left(\mathrm{Y}_{1-\mathrm{x}} \mathrm{Sm}_{\mathrm{x}}\right)_{14.3 \mathrm{~F}} \mathrm{Fe}_{80.0} \mathrm{~B}_{5.7}(\mathrm{x}=0 \sim 0.20)$ で秤量し，アルゴン雾囲気 中で高周波溶解，鋳造しインゴットを得た。得られたイン ゴットをアルゴン雲囲気中で $1473 \mathrm{~K}, 20$ 時間の均質化処理後, $63 \sim 500 \mu \mathrm{m}$ に粗粉研し, 続いて遊星ボールミルで $3 \mu \mathrm{m}$ 程度 に粉砕した.

得られた粉末の相の同定には XRD (理学電機製 RAD-C: Fe 管球)，磁気特性の測定にはVSM (理研電子製BHV-30 型：最 大印加磁界 $1.2 \mathrm{MA} / \mathrm{m}$ ) を用いた. VSM 測定用試料は, ダイフ ロン製カプセル (内径 $6 \mathrm{~mm}$, 深さ $3 \mathrm{~mm}$ ) 中に試料粉末とパラ フィンを入れ，パラフィンを溶かした後 $0.96 \mathrm{MA} / \mathrm{m}$ の磁界を 印加させながらパラフィンを固化させて作製した.

次に得られた粉末を $6 \mathrm{mass} \%$ のシランカップリング剂で表 面処理し，アセトンに溶かしたエポキシ樹脂と質量比 8:2で 混合した. その後 $373 \mathrm{~K}$ のホットプレート上でアセトンを擋拌 しながら蒸発させ樹脂によって被覆された粉末を得た。これ を圧粉後， $453 \mathrm{~K}$ で熱硬化させた．この樹脂複合体を Fig.1に 示すように測定冶具形状に合わせて加工し，電磁波吸収特性 測定試料とした.

電磁波吸收特性は $0.5 \sim 40 \mathrm{GHz}$ の帯域ではベクトルネット ワークアナライザ (Agilent Technologies 社製 8722ES) を，50 〜 $75 \mathrm{G} \mathrm{Hz}$ ではスカラーネットワークアナライザ (Agilent Technologies 社製 8757D) を用いて測定した．前者では試料を

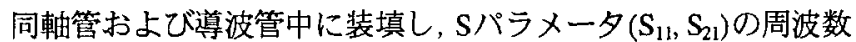
分散を測定し，その測定結果より複素比透磁率 $\mu_{r}\left(=\mu_{r}{ }^{\prime}-j \mu_{r}{ }^{\prime \prime}\right)$ および複素比誘電率 $\varepsilon_{r}\left(=\varepsilon_{r}{ }^{\prime}-j \varepsilon_{r}{ }^{\prime \prime}\right)$ の周波数分散を算出した. 後者での $\mu_{\mathrm{r}}$ の周波数分散の導出フローチャートをFig.2に示

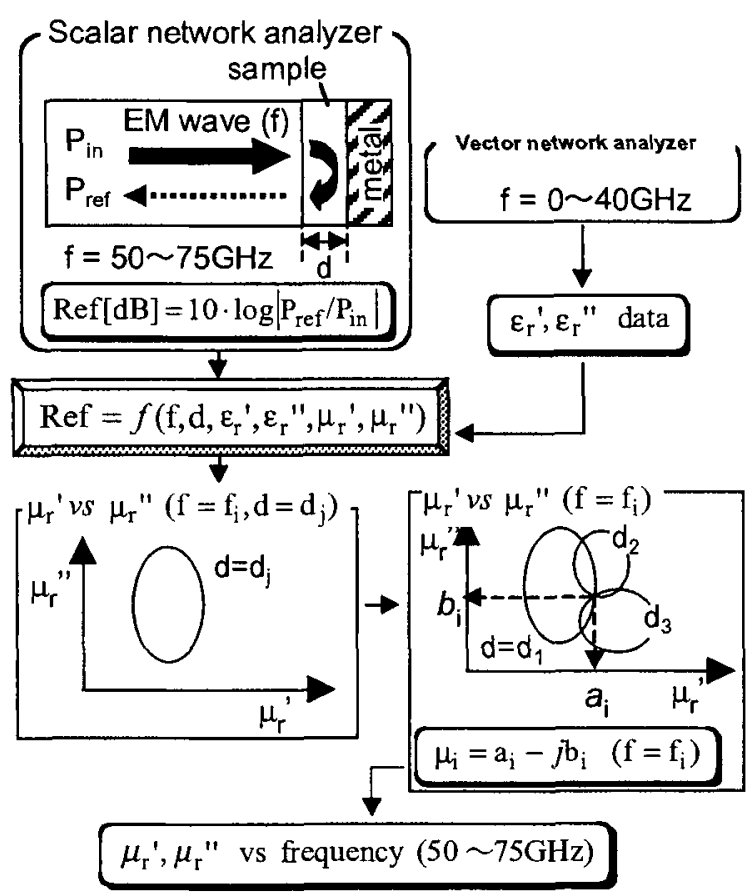

Fig.2 Estimation process of the frequency dependence of $\mu_{\mathrm{r}}$ using a scalar network analyzer. 
す.まずスカラーネットワークアナライザにより金属板で裏 打ちした試料の反射保数 Ref の周波数分散を測定する。 また 本研究で用いた樹脂複合体では，10GHz以上の帯域で $\varepsilon_{\mathrm{r}}$ はほ ぼ一定であると考えられることから，40GHz以下の測定值を 参照する.ここでRefは $\mu_{\mathrm{r}}, \varepsilon_{\mathrm{r}}$ のほか周波数f, 試料厚さdによっ て決まるため, f, d を決めると測定された Ref を満たす $\mu_{\mathrm{r}}{ }^{\prime}$ と $\mu_{\mathrm{r}}{ }^{\prime}$ の組み合わせ ( 円状の Cole-Cole プロット)が得られる. 3 つ以上の厚さの異なる試料で測定することでCole-Coleプロッ トの交点が得られ，それを正味の $\mu_{\mathrm{r}}^{\prime}$ と $\mu_{\mathrm{r}}^{\prime}$ とした。 これを各 周波数で行うことにより $\mu_{\mathrm{r}}$ の周波数分散を得た. 電磁波吸収

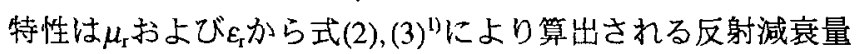
(R.L.) 用いて評価した.

$$
\begin{aligned}
& Z_{\text {in }}=Z_{0} \sqrt{\mu_{r} / \varepsilon_{r}} \tanh \left(j(2 \pi f d / c) \sqrt{\mu_{r} \varepsilon_{r}}\right) \\
& \text { R.L. }=20 \log \left|\left(Z_{\text {in }}-1\right) /\left(Z_{\text {in }}+1\right)\right|
\end{aligned}
$$

ここで, $\mathrm{Z}_{\text {in }}$ は吸収体前面の入カインピーダンス, $\mathrm{Z}_{\mathrm{o}}, \mathrm{c}$ は真空 のインピーダンスおよび光速である.

\section{$3 \quad\left(\mathrm{Y}_{1-\mathrm{x}} \mathrm{Sm}_{\mathrm{x}}\right)_{2} \mathrm{Fe}_{14} \mathrm{~B}$ 粉末の磁気特性}

まず $\mathrm{x}=0.12$ の試料の均質化後およびミル粉砕後のX線回折 パターンをFig.3に示す. どちらの試料についても正方晶 2-14-1 型の回折パターンが得られている.ただしミル粉砕後の試料 の $2 \theta=57^{\circ}$ 付近 $(\alpha-\mathrm{Fe}$ 相の(110)面および2-14-1相の(314),(331) の回折角)のピーク相対強度比が微増していることから, 粉砕 時に酸化が進行し $\alpha-\mathrm{Fe}$ が出現した可能性が高いと考えられ る.なお $\mathrm{Sm}$ 置換量の異なる試料についても同様の傾向が見ら れた。

続いて各ミル粉研粉末を配向した試料についてVSMで磁化

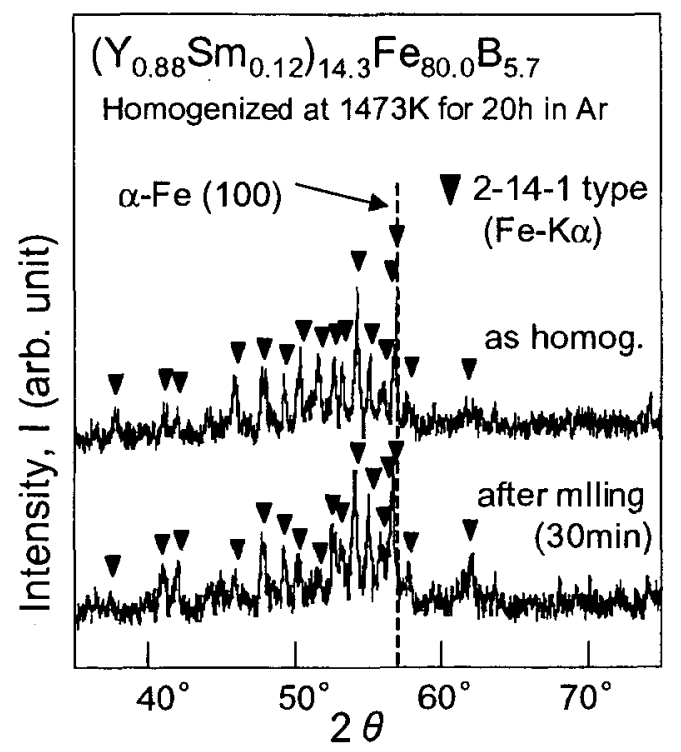

Fig.3 X-ray diffraction patterns of the $\left(\mathrm{Y}_{0.88} \mathrm{Sm}_{0.12}\right)_{14.3} \mathrm{Fe}_{80.0} \mathrm{~B}_{5.7}$ powders.
曲線を測定した. 各試料の飽和磁化は1.15〜 1.25Tであった. これらの值は $\mathrm{Y}_{2} \mathrm{Fe}_{14} \mathrm{~B}$ の理論値である $1.42 \mathrm{~T}$ に比べ $10 \sim 20 \%$ 程度低いが，これは出発組成を $\alpha-\mathrm{Fe}$ 相析出抑制のために希土 類リッチ組成としたためであると考えられる.Fig.4に飽和磁 化で規格化した磁化曲線を示した.太線が配向方向に平行に， 細線が配向方向に垂直に磁界を印加した時の磁化曲線である. Sm置換量xが増加するに従い垂直方向の磁化曲線が平行方向 の曲線に近づいていき， $x=0.12 て ゙$ 最も近づいた．それ以上の 置換量では逆に離れていった.このことから $\mathrm{x}=0.12$ 付近で結 晶磁気異方性が一軸から面内に変化したものと考えられる. そこで $\mathrm{x}=0 \sim 0.12$ の試料については一軸磁気異方性, $\mathrm{x}=0.15$ 〜0.20の試料については面内磁気異方性と仮定し, 異方性磁 界の算出を試みた。一軸磁気異方性の試料に関してはSPD法 を用いた。 また面内異方性の試料については，2-14-1 相が正 方晶であり c 面内の困難軸が 4 回対称 ([110] 方向が面内困難 軸9) であることを利用して以下のように導出した．まず配向 方向と平行・垂直方向に加え $45^{\circ}$ 方向の磁化曲線も測定しSPD 法を用いて $45^{\circ}$ 方向 $\left(\mathrm{H}_{\mathrm{A}}(45)\right)$ および $90^{\circ}$ 方向 $\left(\mathrm{H}_{\mathrm{A}}(90)\right)$ の異方性 磁界を導出する．ここでFig.5のような座標系を考える. x 軸 が配向方向 (平行の測定方向), $\mathrm{y}$ 軸が垂直の測定方向である. また粉末面内容易軸を $\alpha_{0}$ ([100]方向), 面内, $\mathrm{c}$ 軸の困難軸 をそれぞれ $\alpha_{1}$ ([110]方向)， $\alpha_{2}$ ([001]方向)とし，さらにそれ ぞれ困難軸の異方性磁界を $\mathrm{H}_{\mathrm{A} 1}, \mathrm{H}_{\mathrm{A} 2}$ とする.このとき測定力プ セル中での粉末において配向が完全であると仮定すると， $\alpha_{0}$ は 常にx 軸方向， $\alpha_{2}$ は常にyz面内方向となり $\alpha_{1}$ はx 軸を母線と した円錐面方向となる， $\alpha_{1}$ は 4 回対称， $\alpha_{2}$ は2 回対称である から $\mathrm{H}_{\mathrm{A}}(45)$ には $\mathrm{H}_{\mathrm{Al}}, \mathrm{H}_{\mathrm{A} 2}$ 共に奇与するが， $\mathrm{H}_{\mathrm{A}}(90)$ には $\mathrm{H}_{\mathrm{A} 1}$ は

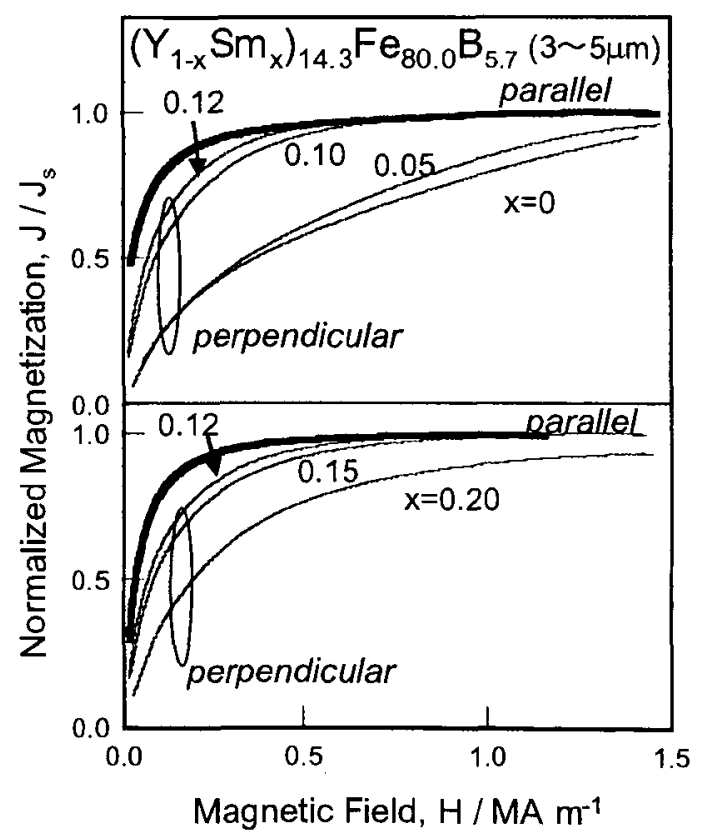

Fig.4 Variation of normalized magnetization curves in $\left(\mathrm{Y}_{1-\mathrm{x}} \mathrm{Sm}_{\mathrm{x}}\right)_{14.3}$ $\mathrm{Fe}_{80.0} \mathrm{~B}_{5.7}$ powders $(\mathrm{X}=0-0.20)$ vs Sm content $(\mathrm{X})$. 


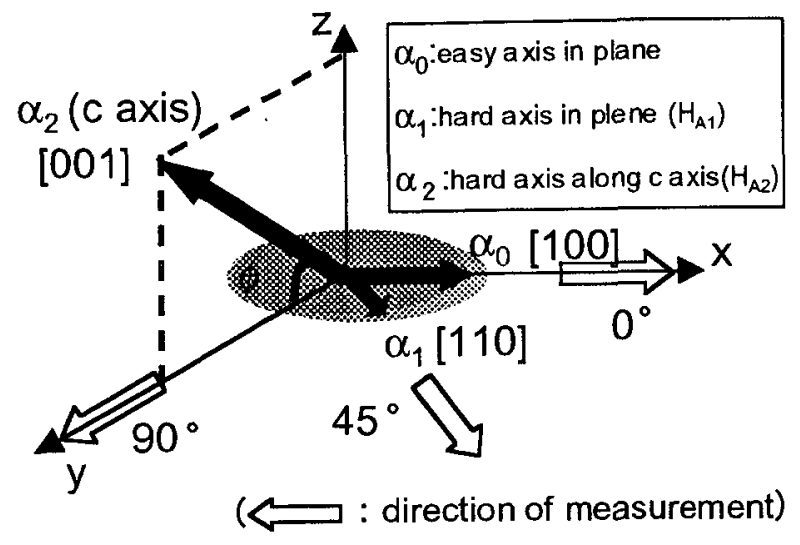

Fig.5 The coordinate system for the estimation of anisotropy field.

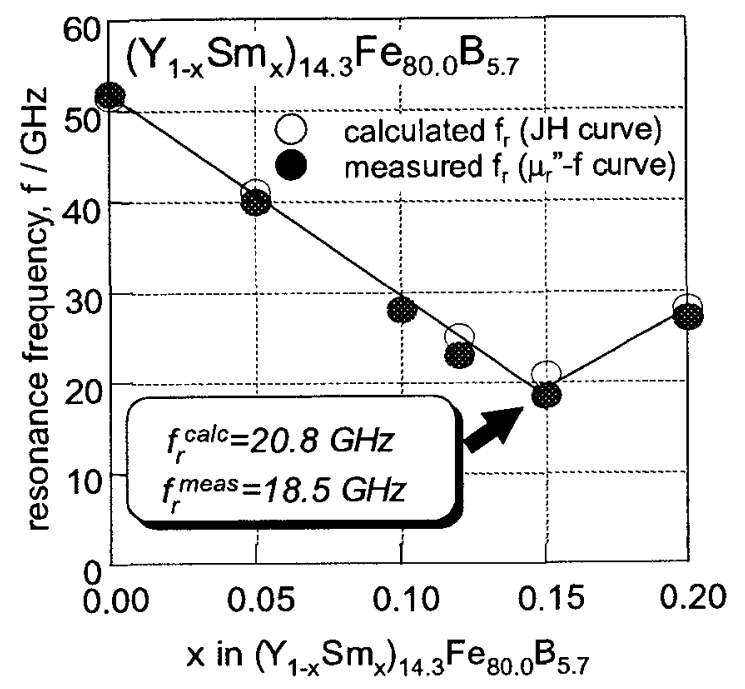

Fig.6 Variation of resonance frequency (calculated from anisotropy field, $f_{r}^{\text {calc. }}$ : white circle, estimated from $\mu_{r}-f$ curves, $f_{r}^{\text {meas }}$ : black circle) with the Sm content $(\mathrm{x})$ in $\left(\mathrm{Y}_{1-\mathrm{x}} \mathrm{Sm}_{\mathrm{x}}\right)_{14.3} \mathrm{Fe}_{80.0} \mathrm{~B}_{5.7}$ powders $(\mathrm{x}=0 \sim 0.20)$.

寄与せず $\mathrm{H}_{\mathrm{A} 2}$ のみで決まる. $\alpha_{2}$ と $90^{\circ}$ 測定方向 $(\mathrm{y}$ 軸) との成す 角を $\phi$ とし，また $\alpha_{1}$ および $\alpha_{2}$ と $45^{\circ}$ 測定方向の成す角をそれ ぞれ $\phi_{1}, \phi_{2}$ と置くと $\mathrm{H}_{\mathrm{A}}(45), \mathrm{H}_{\mathrm{A}}(90)$ は $\mathrm{H}_{\mathrm{A} 1}, \mathrm{H}_{\mathrm{A} 2}$ を用いて (4), (5) 式のように書ける。

$$
\begin{aligned}
& H_{A}(45)=(1 / 2 \pi)\left(\int H_{A 1} \cos \phi_{1} d \phi_{1}+\int H_{A 2} \cos \phi_{2} d \phi_{2}\right) \\
& H_{A}(90)=(1 / 2 \pi) \int H_{A 2} \cos \phi d \phi
\end{aligned}
$$

これらの式を用いて面内異方性の異方性磁界を求めた。ま

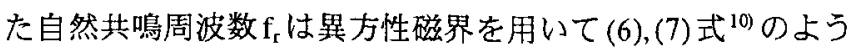
に与えられる。

$$
\begin{array}{ll}
f_{r}=(\gamma / 2 \pi) H_{A} & \text { (一軸異方性) } \\
f_{r}=(\gamma / 2 \pi) \sqrt{H_{A 1} H_{A 2}} & \text { (面内異方性) }
\end{array}
$$

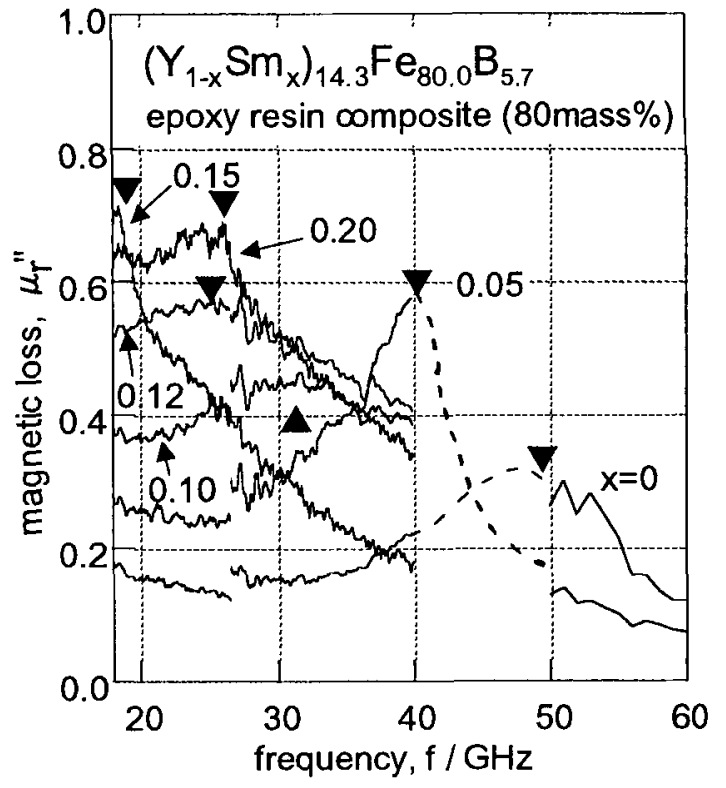

Fig.7 Frequency dependence of $\mu_{\mathrm{r}}$ " of $\left(\mathrm{Y}_{1-\mathrm{x}} \mathrm{Sm}_{\mathrm{x}}\right)_{14.3} \mathrm{Fe}_{80.0} \mathrm{~B}_{5.7}(\mathrm{x}=0$ $\sim 0.20$ ) resin composites.

ここで $\gamma$ は磁気回転比である. Fig.6に異方性磁界および (6), (7)式から計算された $\mathrm{f}_{\mathrm{r}}$ のSm置換量 $\mathrm{x}$ に対する依存性を図 中の白丸にて示した.これより $\mathrm{f}_{\mathrm{r}}$ は $\mathrm{x}$ と共に值線的に低下し， $\mathrm{x}=0.15$ で極小值 $20.8 \mathrm{GHz}$ をとり $\mathrm{x}=0.20$ では再び增加するこ とがわかる。

\section{4 自然共嗎現象之電磁波吸収特性}

続いて得られた磁性粉末のエポキシ樹脂複合体を作製し， ネットワークアナライザで $\mu_{\mathrm{r}}, \varepsilon_{\mathrm{r}}$ の周波数分散を測定した. こ れらの複合体試料における体積充填率は $23 \mathrm{vol} \%$ であった. $40 \mathrm{GHz}$ 以下の帯域で, これらの複合体試料の複素比誘電率は $\varepsilon_{\mathrm{r}}^{\prime}=14 \sim 18, \varepsilon_{\mathrm{r}}{ }^{\prime \prime}=0.5 \sim 1.5$ と絶縁性が十分であり，また周波数 に対しほぼ一定檤となった. Fig.7に磁性損失項 $\left.\left(\mu_{\mathrm{r}}\right)^{\prime}\right)$ の周波数 分散の測定結果を示す.それぞれの試料において $\mu_{\mathrm{r}}$ "のブロー ドなピークが見られる. $\mathrm{x}$ の值が大きくなると共に中心周波数 $\mathrm{f}_{\mathrm{r}}^{\text {meas }}$ は低下していき, $\mathrm{x}=0.15$ の試料で最小值 $18.5 \mathrm{GHz}$ となっ た. $\mathrm{x}=0.20$ では逆に $\mathrm{f}_{\mathrm{r}}^{\text {meas }}$ は上昇した.この $\mathrm{f}_{\mathrm{r}}^{\text {meas }}$ を Fig.6 中に 示した(黒丸)ところ，異方性磁界からの算出值とよく一致し た. 従ってこれらの $\mu_{\mathrm{r}}{ }^{\mathrm{N}}$ のピークは自然共鳴によるものといえ る. 傾向としては高周波側のピークほど強度が小さくなって いるが，これは高周波側ほど表皮厚さが小さくなり渦電流に よる励起磁化の低下が大きくなったためと考えられる.

得られた $\mu_{\mathrm{r}}, \varepsilon_{\mathrm{r}}$ から R.L.を計算した結果をFig.8に示す。 な お吸収体厚さは共鳴周波数付近で最高の電磁波吸収特性が得 られる厚さとした. 電磁波吸収の得られる周波数はFig.6に示 した共鳴周波数に近く, $\mathrm{x}=0.15$ の試料では約 $15 \mathrm{GHz}$ の吸収中 心周波数となった. たとえば将来の無線LANが使用を予定し ている周波数の一つである $22 \mathrm{GHz}$ 近傍に着目すると, $\mathrm{x}=0.10$ 


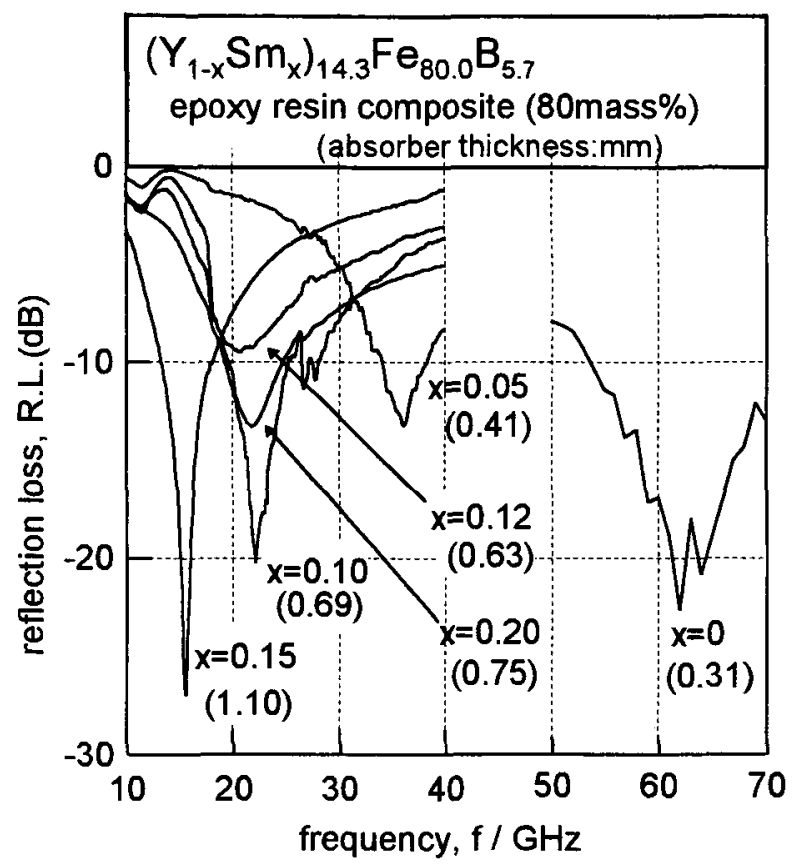

Fig.8 Frequency dependence of R.L. of $\left(\mathrm{Y}_{1-\mathrm{x}} \mathrm{Sm}_{\mathrm{x}}\right)_{14.3} \mathrm{Fe}_{80.0} \mathrm{~B}_{5.7}(\mathrm{x}=0$ $\sim 0.20$ ) resin composites.

の試料で吸収体厚さ $0.69 \mathrm{~mm}$ において R.L. $=-20.2 \mathrm{~dB}$ と十分 な吸収が得られている.この値は太田ら ${ }^{11)}$ がBaM型フェライ 卜樹脂複合体において報告している $22 \mathrm{GHz}$ での吸収体厚さ $1.1 \mathrm{~mm}$ と比較すると $30 \%$ 小さい值である. 十分な吸収の得ら れなかった試料に対しても，樹脂の種類や充填率を調整して $\mu_{r}, \varepsilon_{\mathrm{r}}$ の周波数分散を制御すれば電磁波吸収特性が改善される 可能性があり， $\left(\mathrm{Y}_{1-x} \mathrm{Sm}_{\mathrm{x}}\right)_{2} \mathrm{Fe}_{14} \mathrm{~B}$ 化合物を用いて $15 \sim 60 \mathrm{GHz}$ の 範囲で任意周波数に対応した電磁波吸収体の設計が可能であ るといえる.

\section{5 結 論}

本研究ではマイクロ波帯域用電磁波吸収体として希土類一 鉄一ボロン系化合物の利用を険討し, 以下の結論を得た.
(1) $\left(\mathrm{Y}_{1-\mathrm{x}} \mathrm{Sm}_{\mathrm{x}}\right)_{2} \mathrm{Fe}_{14} \mathrm{~B}$ 化合物 $(\mathrm{x}=0 \sim 0.20)$ において, $\mathrm{Sm}$ 置換量 $\mathrm{x}$ の増加と共に一軸磁気異方性が減少し, $\mathrm{x}=0.12$ 付近で面 内磁気異方性に変化した. また異方性磁界から計算される 共鳴周波数は $\mathrm{x}=0.15$ のとき $20.8 \mathrm{GHz}$ と最小となった.

(2) 充填率 $80 \mathrm{mass} \%(23 \mathrm{vol} \%)$ )樹脂複合体において，それぞ れ異方性磁界から求められた共鳴周波数付近で磁性損失の 增大が確認された。

(3) $\mathrm{Sm}$ 置換量を変えることで $15 \sim 60 \mathrm{GHz}$ の範囲で電磁波吸 収のピークが観祭された. 特に $\mathrm{x}=0.10$ の試料では $22 \mathrm{GHz}$ における電磁波吸収に際し，吸収体厚さがM 型フエライ 卜試料に比べて約 $30 \%$ 薄くなった。

\section{文献}

1) 橋本修: "電波吸収体入門", 森北出版, 東京, (1997).

2) 岡山克已ほか: " $\mathrm{BaFe}_{12-\mathrm{x}}\left(\mathrm{Ti}_{0.5} \mathrm{M}_{0.5}\right)_{x} \mathrm{O}_{19}(\mathrm{M}=\mathrm{Co}, \mathrm{Ni}, \mathrm{Zn}, \mathrm{Mn}, \mathrm{Cu})$ の電磁波吸収特性", 日本応用磁気学会誌, 22(1998)297-300.

3) S.Sugimoto et al.: "Barium M-type Ferrite as an Electromagnetic Microwave absorber in the GHz Range", Mater. Trans. JMM, 39 (1998) $1080-1083$.

4) S.Sugimoto et al.: "M-TYPE FERRITE COMPOSITE AS A MICROWAVE ABSORBER WITH WIDE BANDWIDTH IN THE GHz RANGE", IEEE Trans. Magn., 35(1999)25-27.

5) 内藤喜之: "フェライト吸収壁の厚さについて", 電子通信 学会論文誌, 52-B(1969)21-25.

6) 太田恵造: "磁気工学の基礎而", 共立出版, 東京, (1973)345.

7) 传川真人ほか："Nd- $\mathrm{Fe}-\mathrm{B}$ 系永久磁石材料", 固体物理, 21(1986)37-43.

8) Y.Yang et al:: "MAGNETOCRYSTALLINE ANISOTROPY OF $\left(\mathrm{Nd}_{1-\mathrm{x}} \mathrm{Sm}_{\mathrm{x}}\right)_{2} \mathrm{Fe}_{14} \mathrm{~B}$ AND $\left(\mathrm{Nd}_{1-\mathrm{x}} \mathrm{Pr}_{\mathrm{x}}\right)_{2} \mathrm{Fe}_{14} \mathrm{~B} "$, J. Magn. Magn. Mater., 54-57(1986)895-897.

9) H.Hiroyoshi et al.: "MAGNETIC ANISOTROPY OF $\mathrm{Sm}_{2} \mathrm{Fe}_{14} \mathrm{~B}$ SINGLE CRYSTAL", Solid State Comm., 54(1985)41-43.

10)金子秀夫，本間基文："磁性材料"，日本金属学会，仙台， (1977)123.

11) 太田博康ほか: 2000 年電子情報通信学会ソサエティ大会講 演論文集, B-7-9(2000). 